\title{
Jak /ne/zvýšit kvalitu vysokých škol
}

\author{
Vážení čtenár̆i,
}

od podpisu Boloňské deklarace uplynulo v letošním roce již třináct let. Pokud čteme cíle, které za touto deklarací a navazujících dokumentů stály, nelze jim upřít snahu o rozvoj vysokého školství v Evropské unii. I po třinácti letech však zůstává otázkou, zdali cesty, na kterých je celý tento proces založen, jsou takové, že k těmto cílům povedou.

O potřebě zvýšit kvalitu našich vysokých škol slyšíme v posledních letech v různě silných vlnách prakticky nepřetržitě. Kolik jen za poslední roky vzniklo návrhů, jak reformovat vysoké školy, kolik času nad nimi spoustu lidí strávilo, kolik peněz to celé stálo - a výsledek? Každoroční kosmetické změny ve financování škol spojené s limitováním počtu studentů na veřejných školách, které akorát komplikují školám úvahy pro horizont překračující jeden rok, ale jiný užitek př́liš nepřinášejí. To vše zpestřené občasnými spory o udělení či neudělení nějaké akreditace.

Příčin, proč se o reformě vysokých škol více hovoří, než se činí, je samozřejmě celá řada, vedle politických důvodů $\mathrm{k}$ nim patří určitě i neujasněnost $\mathrm{v}$ tom, jaké změny naše vysoké školy vlastně potřebují. Není pochyb o tom, že naše vysoké školy se neobjevují na předních místech mezinárodních žebrríčků a bude třeba hodně úsilí, aby se tam dostaly. Na druhou stranu si troufám tvrdit, že úroveň řady našich vysokých škol se v posledních letech zvýšila, a proto paušálně říkat, že vysoké školství potřebuje zásadní reformu, je hodně povrchní. Může to navíc vyvolávat pocit, že máme kouzelný proutek, jehož mávnutím dokážeme naše školy na přední místa těch žebř́íčku dostat. Takový nástroj nikdo nemá, na druhou stranu samozřejmě pro zvýšení úrovně vysokých škol prostor existuje, otázkou však je, jaké cesty vedou tím správným směrem.

Problém zásadní je v tom, že měřit kvalitu vysoké školy není vůbec jednoduché. Hlavní výstupy vysoké školy lze vidět ve dvou oblastech: věda a výzkum a absolventi. Pokusy měřit kvalitu v obou oblastech existují, ale mají celou řadu problémů, určitě na jejich základě lze obtížně objektivně stanovit kvalitu té které vysoké školy. Neexistuje žádný jeden ukazatel, ve snaze zahrnout více kritérií potom vždy bude hodně záviset na tom, čemu se dá jaká váha. Navíc obtížnost měřit či posoudit objektivně kvalitu řady výstupů nutně sklouzává $\mathrm{k}$ tomu, že se měří či posuzuje to, co měřitelné či relativně snadno hodnotitelné je, často však již kvalitu vyjadřuje velmi vzdáleně (např. kvalita publikační činnosti se poměřuje spíše počtem publikací, nežli vlastním obsahem, u měření „,kvality“ absolventů je to ještě obtížnější).

Vzhledem k tomu, že posouzení kvality vysoké školy, neřkuli nějakého konkrétního programu či oboru, je objektivně velmi těžké, nelze podle mého názoru čekat, že kvalitu vysokého školství nám může zajistit detailní akreditační proces. Již představa, budeme schopni vytvořit orgán, který by byl schopen objektivně a kompetentně posoudit to, zdali ta či ona škola je schopna realizovat na kvalitní úrovni ten či onen obor, je mylná. Vezmeme-li počet škol a oborů, jejich rozmanitost, řada z nich se navíc dynamicky rozvíjí, nemůže být v silách akreditačního orgánu toto obsáhnout. Navíc již jen fakt, že posuzování provádějí lidé $\mathrm{z}$ de facto konkurenčních škol je z řady hledisek problematické.

Další iniciativou poslední doby, která se snaží o zvýšení kvality vysokých škol, je projekt Q-RAM. Již samotná představa, že je někdo schopen stanovit, co by měl přesně znát 
absolvent určitého oboru, je velmi sporná. Pokud to bude postihovat pouze základní obecný rámec stěžejních předmětů oboru, asi nebude mít velký význam - málokterá škola by se do toho nevešla. Pokud bude více konkrétní, budeme již narážet na to, že bude nejen těžké takový rámec definovat, ale hlavně to může školy až př́liš svazovat a bránit rozvoji nových prístupů. Rozvoj vysokých škol totiž nelze vidět v tom, že je budeme sjednocovat, naopak pouze v soutěži rozdílných př́istupů se může ukázat, který je nejlepší! Ale navíc - pokud bychom připustili, že jsme rámec daného oboru schopni definovat, jak se bude kontrolovat jejich naplňování? Opsat je do formulářů pro akreditaci, bude asi velmi snadné, takže z nich toho asi moc poznat nepůjde. A že by někdo kontroloval, jak skutečně výuka naplňuje napsaný obsah?

Snaha zvýšit kvalitu vysokého školství prostřednictvím administrativně formalizovaných postupů je přirozená. Je to způsob relativně snadno proveditelný a spoustě lidí se bude jevit i jako správný. Podle mého názoru však od něj žádné pozitivní změny v kvalitě vysokých škol čekat nelze, připočteme-li k tomu náklady s tím spojené - finanční i časové - lze spíše hovořit o opaku.

Cesta ke zvýšení kvality vysokých škol nebude jednoduchá ani krátká. Povede spíše přes vyšší odpovědnost samotných vysokých škol a zároveň větší nároky na „odběratele výstupü“ z vysokých škol při výběru, jaké absolventy či vědecké výstupy budou odebírat. Tady by se měla ukázat i rozdílná úroveň škol. I stát jako odběratel výstupů by měl mnohem ve větší míre klást důraz na úroveň vědeckých výstupů a zaměstnávaných vysokoškolských absolventů. Např. paušální požadavek na vysokoškolské vzdělání pro nějaké místo ve státní správě bez ohledu o jaké vzdělání a na jaké škole jde, je přesně tím, co podporuje nízkou kvalitu některých škol. A stát jako garant celkového vzdělávacího systému? Opustit snahy o detailní posuzování jednotlivých oborů, sledovat spíše, jak jednotlivé školy hodnotí „odběratelé výstupư“, podle toho odvodit, kterým školám dát dlouhodobější perspektivu včetně institucionálního financování. Obavy, že dobré vysoké školy větší odpovědnost a samostatnost nepřetaví do vyšší kvality, jsou méně oprávněné než očekávat, že to bude schopen učinit stát prostřednictvím svých administrativně formálních postupů.

doc. Ing. Petr Dvořák, Ph.D.

děkan Fakulty financí a účetnictví

Vysoké školy ekonomické v Praze 